\title{
Future sea-level rise from tidewater and ice-shelf tributary glaciers of the Antarctic Peninsula
}

\author{
Clemens Schannwell ${ }^{\mathrm{a}, \mathrm{b}}$, Nicholas E. Barrand ${ }^{\mathrm{a}}$, Valentina Radićc \\ ${ }^{a}$ School of Geography, Earth and Environmental Sciences, University of Birmingham, \\ Birmingham, UK \\ ${ }^{b}$ British Antarctic Survey, Natural Environment Research Council, Cambridge, UK \\ ${ }^{c}$ Department of Earth, Ocean and Atmospheric Sciences, University of British Columbia, \\ Vancouver, British Columbia, Canada
}

\begin{abstract}
Iceberg calving and increased ice discharge from ice-shelf tributary glaciers contribute significant amounts to global sea-level rise (SLR) from the Antarctic Peninsula (AP). Owing to ongoing ice dynamical changes (collapse of buttressing ice shelves), these contributions have accelerated in recent years. As the AP is one of the fastest warming regions on Earth, further ice dynamical adjustment (increased ice discharge) is expected over the next two centuries. In this paper, the first regional SLR projection of the AP from both iceberg calving and increased ice discharge from ice-shelf tributary glaciers in response to ice-shelf collapse is presented. An ice-sheet model forced by temperature output from 13 global climate models (GCMs), in response to the high greenhouse gas emission scenario (RCP8.5), projects AP contribution to SLR of $28 \pm 16$ to $32 \pm 16 \mathrm{~mm}$ by 2300 , partitioned approximately equally between contributions from tidewater glaciers and ice-shelf tributary glaciers. In the RCP4.5 scenario, sea-level rise projections to 2300 are dom-
\end{abstract}

Email address: cxs400@bham.ac.uk (Clemens Schannwell)

Preprint submitted to Earth and Planetary Science Letters

July 18, 2016

(C) 2016. This manuscript version is made available under the Elsevier user license http://www.elsevier.com/open-access/userlicense/1.0/ 
inated by tidewater glaciers $(\sim 8-18 \mathrm{~mm})$. In this cooler scenario, $2.4 \pm 1 \mathrm{~mm}$ is added to global sea levels from ice-shelf tributary drainage basins as fewer ice-shelves are projected to collapse. Sea-level projections from ice-shelf tributary glaciers are dominated by drainage basins feeding George VI Ice Shelf, accounting for $\sim 70 \%$ of simulated SLR. Combined total ice dynamical SLR projections to 2300 from the AP vary between $11 \pm 2$ and $32 \pm 16 \mathrm{~mm}$ sea-level equivalent (SLE), depending on the emission scenario used. These simulations suggest that omission of tidewater glaciers could lead to a substantial underestimation of the ice-sheet's contribution to regional SLR.

Keywords: Ice dynamics, Sea-level rise, Tidewater glaciers, Ice-shelf collapse, Ice-shelf tributary glaciers

1. Introduction

The Antarctic Peninsula (AP) is a mountainous and heavily glaciated 3 region, dominated by glaciers flowing directly into the sea (henceforth tide4 water glaciers) and into floating ice-shelves (henceforth ice-shelf tributary 5 glaciers). In response to the rapid warming experienced by this region over celerated rate to global sea-level rise (SLR) in recent years (Cook et al., 2005;

Wouters et al., 2015). In addition to an increase in near-surface air temperatures, surface waters of the surrounding ocean have warmed (Meredith and King, 2005). This ocean warming has been accompanied by an acceleration (Pritchard and Vaughan, 2007) and retreat (Cook et al., 2016) of tidewater glaciers, leading to increased ice discharge to the ocean.

Climatological changes have also affected ice-shelf tributary glaciers. Un- 
like tidewater glaciers, ice-shelf tributary glaciers do not flow directly into the ocean, but into a floating ice-shelf. This extension of the grounded ice exerts backstress (buttressing force) on the grounded glacier upstream and thus restrains ice flow. If this buttressing force is reduced or removed, the grounded ice upstream will speed up, thin and discharge more ice into the ocean. This behaviour has been observed at several locations in the AP region (Rott et al., 2002; Scambos et al., 2004; Rignot et al., 2004). Glaciers draining into the Prince-Gustav-Channel and Larsen A embayments are still adjusting to ice-shelf removal, some 20 years after ice-shelf collapse (Rott et al., 2014; Scambos et al., 2014), and are providing a significant portion to the region's SLR (McMillan et al., 2014).

Abrupt ice shelf collapse events in the past have been linked to a combination of atmospheric warming (Vaughan and Doake, 1996; Scambos et al., 2000) and structural weakening as a result of increased basal melting (Pritchard et al., 2012; Holland et al., 2015). Ice-shelves are thought to be structurally weakened prior to collapse by i) hydrofracture of surface crevasses; and, ii) basal melting at the ice-ocean interface. In the latter process, warm ocean water erodes the underside of the ice shelf, thinning it and thus leaving the ice shelf more vulnerable to the process of hydrofracturing (Shepherd et al., 2003). Hydrofracture of surface crevasses occurs primarily when sufficient meltwater is available at the surface of the ice shelf and can wedge open crevasses to cause catastrophic ice-shelf disintegration (Scambos et al., 2004).

Recent studies suggest that other ice-shelf weakening processes such as fracturing and weakening of shear margins may also be important and lead to a progressive weakening of the ice shelf prior to disintegration (Khazendar 
et al., 2015; Borstad et al., 2016). A prime example of this is the progressive mechanical weakening of the remnant Larsen B Ice Shelf over the last 15 years (Borstad et al., 2016). The importance of these processes may, however, vary for individual ice shelves.

While projections of the surface mass balance are forecasted to provide a negative contribution to sea level, this is expected to be offset by sea-level rise contributions from ice dynamical changes (Barrand et al., 2013a). Owing to their short response times to ice dynamical perturbations (e.g. ice-shelf removal) in comparison to the rest of the Antarctic Ice Sheet (Barrand et al., 2013a), AP glaciers are projected to play an important role in the global SLR budget over the next century (Barrand et al., 2013a; Schannwell et al., 2015). Hitherto, ice-sheet modelling studies of the AP have focused on SLR projections from ice-shelf tributary glaciers, ignoring any contributions from tidewater glaciers (Barrand et al., 2013a; Schannwell et al., 2015). Given the observed acceleration and retreat of most tidewater glaciers (Cook et al., 2005; Pritchard and Vaughan, 2007), this may lead to a substantial underestimation of the SLR contribution from the AP. In this paper, we present the first comprehensive modelling study of SLR projections from both tidewater and ice-shelf tributary glaciers of the AP. Building on the work of Schannwell et al. (2015), ice-shelf collapse timing is not determined by thermal viability limits, but is instead based on the total number of melt days - a more direct and physically-based link to the process of hydrofracture. Daily, rather than monthly near-surface temperature projections are used to provide more sensitive timing estimates of future ice-shelf collapse events. To estimate grounding line retreat in response to ice-shelf removal, a new 
statistical framework is introduced that builds on previous work by Schannwell et al. (2015), improving their statistical parameterisation by relating expected grounding line retreat to the degree of buttressing. Buttressing at the grounding line of each drainage basin is calculated by dividing the normal pressure in presence of an ice shelf by the ocean pressure acting when no ice shelf is present. The combined SLR contribution over the next 300 years is computed, including for the first time the largest 235 tidewater glaciers throughout the northern AP. In addition to this, volume responses of the largest 215 ice-shelf tributary glaciers are simulated. These 450 drainage basins cover a total of $77 \%$ of the AP's area, providing a comprehensive coverage of the Antarctic Peninsula Ice Sheet (APIS).

\section{Data and Methods}

\subsection{Climate data and preprocessing}

In order to estimate the timing of future ice-shelf collapse events, daily near-surface temperature fields from 13 GCMs from the Coupled Model Intercomparison Project Phase 5 (CMIP5) (Taylor et al., 2011) were selected using the Representative Concentration Pathway (RCP)4.5 (Vuuren et al., 2011) and RCP8.5 emission scenarios. The selection of the GCM forcings are provided in Figure A.6 and follows Schannwell et al. (2015). Temperature projection fields were bias-corrected against monthly ERA-Interim data from the European Centre for Medium Range Weather Forecasts (ECMWF; Dee et al., 2011) by shifting the future temperature fields by the average bias for each month between the GCM and ERA-Interim temperatures over the period 1979-2005 (Radić et al., 2014). The bias-corrected temperatures 
were then compared to surface station data (Table B.2) from the AP. The remaining temperature difference between bias-corrected temperature fields and surface station data is attributed to an inaccurate height representation in the temperature fields caused by the relative coarse spatial resolution of the models $\left(\sim 0.75^{\circ}\right)$. Owing to the rugged topography of the AP, this can introduce significant temperature differences (Jones and Lister, 2014). To correct for this, temperature fields were shifted by a temperature-height correction factor derived for each month from every station. As most surface stations are clustered in the north of the AP, temperature data from automatic weather stations were additionally included to improve spatial coverage. A list of stations is provided in the appendix (Table B.2). Height correction factors were then bi-linearly interpolated and extrapolated to provide an ice-sheet wide correction map for each month.

The same sample of GCMs was selected for monthly ocean surface temperature fields which were bias-corrected against the Extended Reconstructed Sea Surface Temperature (ERSST) v4 reanalysis product (Huang et al., 2015) using the same methods as for the surface temperature fields. A plot of the bias for each GCM is provided in the appendix.

\subsection{Tidewater glaciers}

A substantial portion of the mass loss of ice sheets and near-polar glaciers comes from calving (Rignot and Kanagaratnam, 2006; Benn et al., 2007a; Barrand et al., 2013b). While the importance of iceberg calving has been recognised and a number of empirical calving laws have been proposed (Brown et al., 1982; van der Veen, 1996; Benn et al., 2007b; Alley et al., 2008; Luckman et al., 2015), modelling iceberg calving remains a major source of un- 
certainty in ice-sheet models (O'Leary and Christoffersen, 2013). Unlike the rest of the Antarctic Ice Sheet, the AP is located in a maritime climate, experiencing significant surface melt during the austral summer. These characteristics, combined with small- to medium-size calving fronts, demonstrate strong similarity to tidewater glacier systems in Alaska, Svalbard, and coastal Greenland. In the absence of a universal calving law, a scenario-type approach was employed utilising three different types of calving criteria which have been used to successfully simulate calving front retreat in at least one of these regions (Brown et al., 1982; van der Veen, 1996; Luckman et al., 2015). Each calving criterion is assessed in a separate simulation.

The first criterion (henceforth, water depth) relates calving rate to water depth (e.g Brown et al., 1982), using the updated formula from Pelto and Warren (1991)

$$
V_{c}=70+8.33 D_{w}
$$

where $V_{c}$ is the calving rate in $m y r^{-1}$ and $D_{w}$ is the water depth in $m$ at the calving front.

The second criterion (henceforth, flotation criterion) follows van der Veen (1996) who argues that the calving front position is controlled by water depth and ice thickness, following the relationship:

$$
H_{c}=\frac{\rho_{w}}{\rho_{i}} D_{w}+H_{0}
$$

where $H_{c}$ is the critical thickness, $\rho_{w}$ and $\rho_{i}$ are water and ice densities, respectively, and $H_{0}$ represents the minimum thickness above the flotation thickness. Based on modelling studies from Columbia Glacier, Alaska (van der Veen, 1996), this parameter is set to $50 \mathrm{~m}$ in our experiments. Equation 2 
does not provide a calving rate, but rather states that if the calving front thickness becomes less than a critical thickness $H_{c}$, the calving front becomes unstable and retreats by calving icebergs.

Recent studies have highlighted the importance of ocean temperatures and submarine melting to calving (e.g. Straneo et al., 2010; Luckman et al., 2015). Luckman et al. (2015) derived a linear relationship between water temperature and calving rate for 3 tidewater glaciers in Svalbard. Due to the climatic similarities between AP glaciers and Svalbard glaciers, the linear law (henceforth, ocean criterion) was adopted, following the form:

$$
V_{c}=0.35 \times T
$$

where $V_{c}$ is in m per month and $T$ is the ocean temperature between 20-60 $\mathrm{m}$ in ${ }^{\circ} \mathrm{C}$. Instead of ocean temperatures between $20-60 \mathrm{~m}$, ocean induced calving simulations are forced by monthly ocean surface temperature projections. Ocean surface temperatures do not provide a good predictor for forecasting short term calving trends as these lead frontal ablation by 1-2 months (Luckman et al., 2015). However, since long-term calving behaviour is investigated, use of ocean surface temperatures is justified. This is corroborated by a comparison over the model domain, between 1995-2004, of mean ocean surface temperatures and temperatures at 20-60 m depth, from the World Ocean Database (Levitus et al., 2013). This comparison provided a mean decadal temperature difference of $0.19 \pm 0.18^{\circ} \mathrm{C}$ between the two data sets. A maximum distance of $100 \mathrm{~km}$ between calving front and ocean pixel was selected, resulting in omission of the CSIRO GCM from further analysis. 


\subsection{Ice-shelf tributary glaciers}

In order to model the ice dynamic contribution from ice-shelf tributary glaciers, two important parameters need to be estimated: i) ice-shelf collapse timing and ii) the expected grounding line retreat in response to ice-shelf removal.

Ice-shelf collapse timing is computed here according to the total number of melt days in a melt year, a direct link to the physical process of hydrofracture. Several studies noted that immediately prior to the collapse of Larsen B Ice Shelf, the number of melt days and thus the number of observed melt ponds increased dramatically (e.g. Scambos et al., 2003; van den Broeke, 2005). A shelf collapse melt day threshold of 102 days was calculated based on observational data from QuikSCAT microwave measurements over Larsen B Ice Shelf (Barrand et al., 2013c), a melt day threshold similar to a range of previously reported values (Scambos et al., 2003; van den Broeke, 2005). Future melt days and ice-shelf collapse timing were computed from an ensemble of 13 CMIP5 GCM runs (see section Climate data and preprocessing).

Ice flux across the grounding line is restrained in the presence of an ice shelf (Schoof, 2007). Following Gudmundsson (2013) the normalised buttressing factor is computed:

$$
\Theta=\frac{N}{N_{0}}
$$

where $N$ is the normal pressure in presence of an ice shelf, defined by

$$
N=\vec{n}_{g l}^{T}\left(R \vec{n}_{g l}\right) .
$$


$N_{0}$ is the ocean pressure acting normal to the grounding when no ice shelf is present

$$
N_{0}=\frac{1}{2} \rho g h
$$

The vector $\vec{n}_{g l}$ is the unit normal to the grounding line and,

$$
R=2 \eta\left(\begin{array}{cc}
2 \frac{d u}{d x}+\frac{d v}{d y} & \frac{1}{2}\left(\frac{d u}{d y}+\frac{d v}{d x}\right) \\
\frac{1}{2}\left(\frac{d u}{d y}+\frac{d v}{d x}\right) & 2 \frac{d v}{d y}+\frac{d u}{d x}
\end{array}\right)
$$

where $\eta$ is the viscosity, $\rho=\rho_{i}\left(1-\frac{\rho_{i}}{\rho_{w}}\right)$, and $h$ is the ice thickness at the grounding line.

Defined by Equation 4, drainage basins are buttressed when $0 \leq \Theta \leq 1$; the ice shelf is actually pulling the grounded ice when $\Theta>1$; and drainage basins are overbuttressed when $\Theta<0$. Overbuttressed (or $\Theta<0$ ) means that ice slows down as it approaches the grounding line, and mass conservation would require that ice thickens towards the grounding line $\left(\frac{d h}{d x}>0\right)$. $\Theta$ was computed for each drainage basin using velocity data from Rignot et al. (2011), viscosity data from output of an ice-sheet model inversion of surface velocity data (Arthern et al., 2015), and ice thickness data from Huss and Farinotti (2014) where available and Bedmap2 (Fretwell et al., 2013) elsewhere. 128 of the 215 ice-shelf tributary drainage basins are buttressed, 52 experience ice-shelf pulling, and 35 drainage basins are overbuttressed. Basins experiencing ice-shelf pulling are characterised by narrow ice fronts with strong shear margins. These basins are omitted from the analysis as we do not expect any ice dynamical adjustment following ice-shelf collapse. While ice dynamical changes may be expected for overbuttressed drainage basins, these glaciers were also excluded from further analysis as Schoof's 
flux formula (Schoof, 2007, equation 29) is not valid for these cases.

The new parameterisation of grounding line retreat is based on the assumption that highly buttressed drainage basins will react more to ice-shelf removal than lightly buttressed basins. Ice flux across the grounding line is computed for each drainage basin for the buttressed and the unbuttressed case $(\Theta=1)$ using Schoof's flux formula (Schoof, 2007). The remaining input data for Schoof's flux formula (basal drag and rheological coefficient) were obtained from output of an ice-sheet model inversion (Arthern et al., 2015).

Adjustment times for drainage basins are scaled to $\Theta$. The maximum mean adjustment time (for infinitesimal positive $\Theta$ ) is set to 20 years, following observations from Larsen A Ice Shelf (Rott et al., 2014) and no mean adjustment time is allowed for $\Theta=1$. In between these bounds, the mean adjustment time is computed using Schoof's $\Theta$ exponent:

$$
M \propto \Theta^{\left(\frac{n}{m+1}\right)}
$$

where $M$ is the mean adjustment time, $n=3$, and $m=1 / 3$.

As mean adjustment times are based on current observations, uncertainties are associated with adjustment times derived from equation 8. To account for this, we allow for uncertainty in the grounding line retreat rates within the bounds of a mean adjustment time. These realisations are set by a gamma distribution with shape parameters $k=M / 1.5$ and $\Theta_{\gamma}=1.5$. The shape parameters represent greater certainty in short adjustment times and less certainty over longer adjustment timescales, allowing wider spread around the mean adjustment time in the latter case (Figure 1a). For each of the 10000 computed adjustment times, a corresponding step-response function 
for $\Theta$ is computed (Figure 1b). This mimics the behaviour observed in the Amundsen Sea Sector of West Antarctica where glaciers have been observed to retreat rapidly, then remain stable, before rapid retreat commences again (Favier et al., 2014). The number of steps in the function and when these steps occur for each step-response function are randomly determined (Figure 1b). However, the maximum number of steps has to be smaller or equal to the adjustment time. The grounding line retreat for each realisation is then computed as follows:

$$
\Delta x_{g l}=\sum_{M=1}^{M} \frac{\left(q_{b g l_{M}}-q_{g l}\right)}{h_{g l}}
$$

Here, $q_{g l}$ is the unbuttressed grounding line flux and $q_{b g l_{M}}$ is the buttressed flux for that year using the updated $\Theta$ value from the step-response function (Figure 1b). The retreat distance for each ice-shelf buttressed drainage basin is determined by taking the mean of the 10000 retreat realisations (see Table 1).

Grounding line retreat of $>1 \mathrm{~km}$ is projected for 22 drainage basins. The vast majority of the drainage basins are expected to show very little retreat. The highest retreat rates are located at drainage basins which are strongly buttressed and possess thick ice at the grounding line. The least retreat in response to ice-shelf collapse is expected for the drainage basins of Larsen B (Scar Inlet) and Larsen C Ice Shelf (Table 1). This is in agreement with independent model simulations suggesting passive shelf ice at Larsen C Ice Shelf (collapse of the shelf will not induce much grounding line retreat at upstream basins (Fürst et al., 2016)). 


\subsection{Model and experimental design}

Ice dynamic contribution to SLR was simulated with the British Antarctic Survey Antarctic Peninsula Ice Sheet Model (BAS-APISM), previously shown to be suitable for the unique topographic setting from the AP (Barrand et al., 2013a; Schannwell et al., 2015). Our simulations comprise two experiments: i) the SLR contribution to 2300 of 235 drainage basins is computed, using a range of empirically-based calving criteria. In the first simulation, iceberg calving is allowed until 2100 and in the second simulation, calving is permitted until 2300. Differing forcing periods for calving were applied to investigate their influence on sea-level projections to the end of the simulation period. In experiment ii) the end members of the calving simulation permitting calving until 2300 are combined with SLR projections from 215 ice-shelf tributary glaciers to estimate the total ice dynamic SLR contribution for the AP. Ice-shelf collapse is permitted until 2300 for all simulations.

\section{Results and Discussion}

\subsection{Sea-level rise from tidewater glaciers}

Simulated SLR projections from tidewater glaciers underline their crucial importance to the regional sea-level budget of the AP region. For the simulation allowing calving to 2100, projections are between $3.2 \pm 1.6 \mathrm{~mm}$ and $18.6 \mathrm{~mm}$, and for the experiment permitting calving to 2300, between $8.7 \pm 2.9$ and $18.6 \mathrm{~mm}$. Uncertainty ranges $( \pm 1 \sigma)$ are available for ocean criterion simulations only. Across the two experiments, differences are present in projections from the ocean criterion, indicating a considerable change in ocean forcing between the emission scenarios (Figure 2). 
Differences in SLR projections are most pronounced in the simulations allowing calving to 2100 (Figure 3a). In these simulations, projections from the ocean criterion are an order of magnitude smaller than projections from the flotation and the water depth criteria. These two calving criteria project the vast majority of their total SLR by 2300 over the next 50 years. This is mainly due to the fact that a few drainage basins (e.g. Fleming Glacier, Wordie Bay) rest on bedrock located well below sea level and thus are very vulnerable to iceberg calving in the flotation and water depth criteria (see equations 1 and 2). In contrast to the projected 18.6 and $13.7 \mathrm{~mm}$ by 2300 from the water depth and flotation criteria respectively, SLR projections using ocean forcing are moderate, projecting $3.2 \pm 1.6 \mathrm{~mm}$ for the RCP4.5 and $5.0 \pm 2.3 \mathrm{~mm}$ for the RCP8.5 emission scenario (Figure 3a).

These differences in SLR projections are smaller in the simulations where iceberg calving is permitted until 2300. While SLR projections from the water depth and flotation criteria remain unchanged, projections from the ocean criterion are an order of magnitude higher and in a very similar range as the other calving criteria (Figure 3b). This means that for the water depth and flotation criteria, all retreat is projected to occur prior to 2100 in all simulations. In contrast SLR projections from the ocean criterion are small to $2050(<1 \mathrm{~mm})$, but increase dramatically after that. The RCP8.5 scenario projects even marginally higher SLR than the flotation criterion at $13.9 \pm 2.1 \mathrm{~mm}$, while scenario RCP4.5 projects a SLR of $8.7 \pm 2.9 \mathrm{~mm}$ by 2300 (Figure $3 b)$.

The larger discrepancy in SLR between the emission scenarios can be explained by the much steeper increase in ocean temperatures for the RCP 8.5 
scenario in the latter two centuries of the simulation period. While there is only a $1.8 \pm 0.7 \mathrm{~mm}$ difference in the first simulation (Figure $3 \mathrm{a}$ ), this difference almost triples to $5.2 \pm 0.8 \mathrm{~mm}$ in the second simulation (Figure $3 \mathrm{~b}$ ). This is also reflected in the ocean temperature projections (Figure 2). In 2100, the temperature difference between the scenarios is $0.6^{\circ} \mathrm{C}$, but increases to $4^{\circ} \mathrm{C}$ by 2300 . The total warming observed in the multi model mean of RCP 8.5 is $4.6^{\circ} \mathrm{C}$ (Figure 2). This ocean warming, however, is not spatially homogeneous. Rather, there are noticeable differences between the west and east coasts of the peninsula. To the west of the peninsula, warming is more pronounced at $0.96^{\circ} \mathrm{C}$ per century, compared to $0.85^{\circ} \mathrm{C}$ for the eastern side of the peninsula. This modelled temperature disparity between the two regions continues the pattern observed in the second half of the 20st century (Meredith and King, 2005).

In the absence of a universal calving law, it is important to note that none of our calving criteria are specifically tuned for the AP. BAS-APISM also cannot simulate glacier front advance. These limitations mean that the SLR numbers reported here should be understood as a first-order estimate of SLR from tidewater glaciers. While surface ocean temperatures appear to be a reasonable approximation of temperatures at depths between 20-60 m, uncertainties remain as to how well these modelled temperatures reproduce near-coastal ocean temperatures. The projected $18.6 \mathrm{~mm}$ from the water depth criterion should be interpreted as a maximum that can be expected from these 235 glaciers. In the simulations using this criterion, the calving front retreats at each drainage basin until the bedrock on which the glacier rests is very close to sea level. 
Evaluating the suitability of calving criteria to project calving rates remains difficult. Studies investigating calving behaviour of individual glaciers in different environmental settings have noted that the processes controlling calving are multi-faceted and may vary for individual glaciers (Nick et al., 2013; James et al., 2014; Luckman et al., 2015). Other studies have successfully reproduced calving retreat rates using simple empirical calving criteria (Vieli et al., 2001; Nick and Oerlemans, 2006). An indication of the general agreement across the calving criteria is provided by the second simulation (Figure 3b), where Fleming and Prospect glacier, Wordie Bay, are the largest single contributors to SLR regardless of the applied calving criteria, projected to contribute between 1.8 - $3.4 \mathrm{~mm}$ to SLR by 2300 .

\subsection{Combined ice dynamical sea-level rise}

The combined SLR projections in the RCP4.5 scenario are dominated by the contributions from tidewater glaciers, accounting between $79 \%$ and $89 \%$ to the combined SLR. There is a very minor contribution from ice-shelf tributary glaciers to 2150, and their contribution to 2300 remains small at $2.4 \pm 1.5 \mathrm{~mm}$. This relative unimportance is due to the absence of ice-shelf collapse (Figure 4). In the RCP4.5 scenario, the multi model mean suggests disintegration of $50 \%$ of the 10 ice shelves (Figure 4). Only one of the ice-shelf tributary glaciers of George VI Central contributes significantly to SLR. This basin is responsible for $67 \%$ of the SLR projected from ice-shelf tributary glaciers, demonstrated by the step in the sea level curve following this shelf collapse in year 2210 (Figure 5).

The overall importance of ice-shelf tributary glaciers to SLR increases in the RCP8.5 scenario (Figure 5b). All 10 ice shelves are projected to disintegrate 
in this simulation (Figure 4). Moreover, collapse timings of ice shelves that collapsed in the RCP4.5 occur earlier in RCP8.5. The later the forecasted ice-shelf collapse in RCP4.5, the larger is the shift in timing in the RCP8.5 scenario. While there is only a 33 year shift for Larsen B North, this shift increases to 168 years for George VI North, the last ice-shelf to collapse in the RCP4.5 scenario (Figure 4).

The collapse of more ice shelves results in much higher SLR projections from ice-shelf tributary glaciers (Figure 4). In contrast to the RCP4.5 scenario, ice-shelf tributary glaciers are as important as tidewater glaciers in this simulation. They contribute $51.4 \%$ and $42.4 \%$ to the $26.7 \pm 16.2$ and $32.3 \pm 16.2$ $\mathrm{mm}$ projected for the combined minimum and the combined maximum, respectively (Figure $5 \mathrm{~b}$ ). These projections increase by another $6 \pm 1.6 \mathrm{~mm}$ if overbuttressed glaciers are taken into account by setting $\Theta$ for each of these drainage basins to the minimum value (maximum buttressing) of all ice-shelf tributary glaciers. As overbuttressed drainage basins violate the Schoof flux formula, these projections should be interpreted with caution and are therefore omitted from the total SLR projections. Since not all SLR projections from tidewater glaciers supply uncertainty ranges, uncertainty ranges for all combined SLR projections are reported as $\pm 2 \sigma$ of ice-shelf tributary glacier simulations.

The relative importance of each ice shelf to overall SLR can be assessed from the step size in the SLR curve triggered by individual ice-shelf collapse responses. While some ice-shelf collapses result in no or only a very minor increase in sea level, there are two major steps present in the sea level curve (Figure 5b). These represent the ice shelves that were identified as the most 
crucial to overall SLR. By far the largest single contributor to SLR is George VI Ice Shelf South, followed by Larsen D Ice Shelf South. The former contributes $7.5 \pm 4.4 \mathrm{~mm}$ by 2300 or $54 \%$ of the total contribution from ice-shelf tributary glaciers, while the latter contributes $2 \pm 1.6 \mathrm{~mm}$ by 2300 or $14 \%$ of the total contribution. Combined, these ice shelves account for $68 \%$ of the total projected SLR from ice-shelf tributary glaciers.

Ice-shelf collapse is based on an empirical parameterisation of the physical process hypothesised as being the principal reason for ice-shelf collapse - surface meltwater-induced hydrofracture. A melt day threshold is likely to be a function of annual accumulation as well, but here we stick to the simplest model mainly due to the lack of observations that would allow for a more complex model. Moreover, this collapse mechanism may not be the sole process driving ice-shelf disintegration (Shepherd et al., 2003; Khazendar et al., 2015) and thus ice-shelf collapse might be mis-forecasted. Grounding line retreat from a gradual loss of buttressing (e.g. through ice shelf thinning), where no collapse occurs, was also omitted. Moreover, bedrock topography is only taken into account for tidewater glacier retreat computations, omitting the potential of marine-ice-sheet instability (MISI, a self-sustained retreat of the grounding line on retrograde sloping bedrock) in ice-shelf tributary drainage basins. While a recent study suggests that widespread MISI is unlikely in the AP (Ritz et al., 2015), there is evidence that some regions may be susceptible to this mechanism (e.g. Scar Inlet and George VI Ice Shelf) (Farinotti et al., 2014; Wouters et al., 2015). Despite these simplifications, the implemented grounding line retreat parameterisation predicts plausible retreat rates in agreement with theoretical considerations. 
In comparison to earlier ice dynamical SLR projections from ice-shelf tributary drainage basins by Schannwell et al. (2015), the projections provided here are slightly higher for the RCP4.5 scenario and slightly lower for the RCP8.5 scenario. Discrepancies in SLR between Schannwell et al. (2015) and this study arise due to the improvement in grounding line retreat and ice-shelf collapse parameterisations here. Unlike in the previous grounding line retreat parameterisation, the new parameterisation permits estimation of uncertainty ranges for each simulation. Moreover, ice-shelf collapse timing is calibrated on observations, providing a more robust approximation for future collapse estimates.

\subsection{Uncertainty assessment}

In order to test the robustness of the modelled SLR projections a suite of sensitivity experiments was performed. Since SLR projections from tidewater glaciers should be understood as a first-order estimate and the three calving criteria provide an envelope of future scenarios, the sensitivity experiments concentrate on ice-shelf tributary SLR contributions.

There are two main sources of uncertainty: climate (ice-shelf collapse timing) and grounding line retreat parameterisation. The influence of climate variability on SLR projections is demonstrated by the difference between the two emission scenarios. In RCP8.5, projections are $\sim 6$ fold higher than in RCP4.5. Nonetheless, the importance of ice-shelf collapse timing in a worst-case scenario is relatively moderate. The most extreme scenario with immediate collapse of all fringing ice shelves leads to an increase of $3.7 \mathrm{~mm}$ $(27 \%)$ in comparison to the projection from RCP8.5. 
How much the position of the grounding line changes in response to ice-shelf collapse is of crucial importance for SLR projections from ice-shelf tributary glaciers. In the parameterisation implemented here, the mean adjustment time is scaled to buttressing and is based on available observations from Larsen A Ice Shelf. Since ice dynamical changes are still ongoing in this area, maximum adjustment time may be underestimated. Grounding line retreat rates for each basin were computed using Schoof's flux formula. To investigate the sensitivity of the results, crucial parameters such as adjustment time and all input data to the flux formula were perturbed by $\pm 20 \%$. Results show that by far the most important parameter is ice thickness at the grounding line. SLR projections from all other perturbed parameters vary by $<46 \%(<4.7 \pm 1.7 \mathrm{~mm})$ in comparison to the reference simulations and lie all within the reported uncertainty ranges. For perturbed ice thicknesses however, SLR projections vary by up to $\sim 400 \%$ ( $53.2 \pm 16.6 \mathrm{~mm}$ ), increasing SLR projections in RCP8.5 to $66.9 \pm 25 \mathrm{~mm}$, more than double the SLR projected for the combined RCP8.5 reference simulation. These results highlight the key importance of accurate estimates of ice thickness at glacier grounding lines.

To investigate the robustness of the results to perturbations to ice velocity, the velocity map was perturbed by adding normally distributed noise ( $\sigma=$ $1 \mathrm{SD}$ of unperturbed velocity map) to the unperturbed velocity map. Ice velocity was used to estimate buttressing at each drainage basin. The perturbed velocity map was used to compute new $\Theta$ values for the 128 modelled drainage basins. Of the 128 normally buttressed basins in the reference simulation, 26 change to being overbuttressed and 31 to being unbuttressed. This 
leaves 71 drainage basins for the perturbed model simulation. Despite the smaller number of drainage basins, change in SLR for the RCP8.5 scenario is negligible $(\sim 1 \%)$ in comparison to the reference simulation, indicating an increase in buttressing for these 70 drainage basins. Average buttressing for these basins increases from 0.59 to 0.43 , negating the effect of fewer drainage basins modelled.

\section{Conclusions}

This paper has presented the first comprehensive modelling study of SLR projections from both tidewater and ice-shelf tributary glaciers of the AP. In total, the ice dynamical response of 450 drainage basins, comprising $77 \%$ of the AP's area, was computed. Tidewater glaciers are an important contributor to the ice dynamic SLR projections from the AP. Omission of tidewater glaciers leads to an underestimation of SLR by $>50 \%$. In the RCP 4.5 scenario, SLR projections are dominated by tidewater glaciers contributing $>75 \%$ of the combined SLR, while tidewater and ice-shelf tributary glaciers contribute about the same to total SLR in the RCP8.5 scenario. If all ice shelves disintegrate, George VI Ice Shelf is the largest single contributor, accounting for $9.8 \pm 5.5 \mathrm{~mm}(70 \%)$ of the total SLR projected from ice-shelf tributary glaciers. This agrees well with an earlier modelling study (Schannwell et al., 2015) and is consistent with present-day observations of AP ice-sheet mass balance (Wouters et al., 2015).

Sensitivity results show uncertainties in SLR projections remain due to calving, ice-shelf collapse, and grounding line retreat parameterisation. SLR 
projections for ice-shelf tributary glaciers are highly sensitive to ice thickness and to a lesser extent ice velocity. To reduce uncertainties further in future simulations, accurate ice thickness and velocity maps are required for computation of buttressing and ice flux across the grounding line.

The Antarctic Peninsula Ice Sheet is projected to contribute between $11 \pm 2$ and $32 \pm 16 \mathrm{~mm}$ to global SLR by 2300 , depending on emission scenario. This corresponds to an annual contribution of $0.04 \pm 0.01 \mathrm{~mm} \mathrm{a}^{-1}$ and $0.11 \pm 0.05$ $\mathrm{mm} \mathrm{a} \mathrm{a}^{-1}$ over the next three centuries, respectively. For comparison, the SLR contribution from the entire Antarctic Ice Sheet derived from satellite observations between 2003-2013 was $0.25 \pm 0.07 \mathrm{~mm} \mathrm{a}^{-1}$ (Martín-Español et al., 2016). These findings underline the continued importance of ice dynamic SLR from the AP, even though the AP comprises only 1\% of the total Antarctic Ice Sheet area.

\section{Acknowledgements}

C.S. was supported by a PhD studentship from the University of Birmingham. The computations described in this paper were performed using the University of Birmingham BlueBEAR HPC service, which provides a High Performance Computing service to the University's research community. See http://www. birmingham.ac.uk/bear for more details. We acknowledge the World Climate Research Programmes Working Group on Coupled Modelling, which is responsible for CMIP, and we thank the climate modeling groups for producing and making available their model output (available at http://pcmdi9.llnl.gov/). For CMIP the U.S. Department of Energys Program for Climate Model Diagnosis and Intercomparison provides coordinat- 
492 ing support and led development of software infrastructure in partnership 493 with the Global Organization for Earth System Science Portals. We also 494 thank Rob Arthern for fruitful discussions and for providing model output 495 data for our computations, and two anonymous reviewers for comments which 496 improved the manuscript. 


\section{References}

\section{References}

Alley, R. B., H. J. Horgan, I. Joughin, K. M. Cuffey, T. K. Dupont, B. R. Parizek, S. Anandakrishnan, and J. Bassis (2008), A simple law for ice-shelf calving, Science, 322(5906), 1344-1344, doi:10.1126/science.1162543.

Arthern, R. J., R. C. A. Hindmarsh, and C. R. Williams (2015), Flow speed within the Antarctic ice sheet and its controls inferred from satellite observations, Journal of Geophysical Research: Earth Surface, 120(7), 11711188, doi:10.1002/2014JF003239.

Barrand, N. E., R. C. A. Hindmarsh, R. J. Arthern, C. R. Williams, J. Mouginot, B. Scheuchl, E. Rignot, S. R. M. Ligtenberg, M. R. Van Den Broeke, T. L. Edwards, A. J. Cook, and S. B. Simonsen (2013a), Computing the volume response of the Antarctic Peninsula ice sheet to warming scenarios to 2200, Journal of Glaciology, 59(215), 397-409, doi: 10.3189/2013JoG12J139.

Barrand, N. E., H. Machguth, and J. O. Hagen (2013b), Observing changes in near-polar glaciers in the northern and southern hemispheres, Eos, Transactions American Geophysical Union, 94(23), 208-208, doi:10.1002/ $2013 \mathrm{EO} 230007$.

Barrand, N. E., D. G. Vaughan, N. Steiner, M. Tedesco, P. Kuipers Munneke, M. R. van den Broeke, and J. S. Hosking (2013c), Trends in Antarctic Peninsula surface melting conditions from observations and regional cli- 
mate modeling, Journal of Geophysical Research: Earth Surface, 118(1), 315-330, doi:10.1029/2012JF002559.

Benn, D. I., C. R. Warren, and R. H. Mottram (2007a), Calving processes and the dynamics of calving glaciers, Earth-Science Reviews, 82(3-4), 143-179, doi:http://dx.doi.org/10.1016/j.earscirev.2007.02.002.

Benn, D. I., N. R. J. Hulton, and R. H. Mottram (2007b), 'Calving laws', 'sliding laws' and the stability of tidewater glaciers, Annals of Glaciology, 46 (1), 123-130, doi:10.3189/172756407782871161.

Borstad, C., A. Khazendar, B. Scheuchl, M. Morlighem, E. Larour, and E. Rignot (2016), A constitutive framework for predicting weakening and reduced buttressing of ice shelves based on observations of the progressive deterioration of the remnant Larsen B Ice Shelf, Geophysical Research Letters, 43(5), 2015GL067,365, doi:10.1002/2015GL067365.

Brown, C. S., M. F. Meier, and A. Post (1982), Calving speed of Alaska tidewater glaciers, with application to Columbia Glacier, USGS Professional Paper, 1258-C, C1-C13.

Cook, A. J., A. J. Fox, D. G. Vaughan, and J. G. Ferrigno (2005), Retreating glacier fronts on the Antarctic Peninsula over the past half-century, Science, 308(5721), 541-544, doi:10.1126/science.1104235.

Cook, A. J., P. R. Holland, M. P. Meredith, T. Murray, A. Luckman, and D. G. Vaughan (2016), Ocean forcing of glacier retreat in the western Antarctic Peninsula, Science, 353(6296), 283-286, doi:10.1126/science. aae0017. 
Dee, D. P., S. M. Uppala, A. J. Simmons, P. Berrisford, P. Poli, S. Kobayashi, U. Andrae, M. A. Balmaseda, G. Balsamo, P. Bauer, P. Bechtold, A. C. M. Beljaars, L. van de Berg, J. Bidlot, N. Bormann, C. Delsol, R. Dragani, M. Fuentes, A. J. Geer, L. Haimberger, S. B. Healy, H. Hersbach, E. V. Hólm, L. Isaksen, P. Kållberg, M. Köhler, M. Matricardi, A. P. McNally, B. M. Monge-Sanz, J. J. Morcrette, B. K. Park, C. Peubey, P. de Rosnay, C. Tavolato, J. N. Thépaut, and F. Vitart (2011), The ERA-Interim reanalysis: Configuration and performance of the data assimilation system, Quarterly Journal of the Royal Meteorological Society, 137(656), 553-597, doi:10.1002/qj.828.

Farinotti, D., E. C. King, A. Albrecht, M. Huss, and G. H. Gudmundsson (2014), The bedrock topography of Starbuck Glacier, Antarctic Peninsula, as determined by radio-echo soundings and flow modeling, Annals of Glaciology, 55 (67), 22-28, doi:doi:10.3189/2014AoG67A025.

Favier, L., G. Durand, S. L. Cornford, G. H. Gudmundsson, O. Gagliardini, F. Gillet-Chaulet, T. Zwinger, A. J. Payne, and A. M. Le Brocq (2014), Retreat of Pine Island Glacier controlled by marine ice-sheet instability, Nature Clim. Change, 4(2), 117121, doi:10.1038/nclimate2094http://www.nature.com/nclimate/journal/ v4/n2/abs/nclimate2094.html\#supplementary-information.

Fretwell, P., H. D. Pritchard, D. G. Vaughan, J. L. Bamber, N. E. Barrand, R. Bell, C. Bianchi, R. G. Bingham, D. D. Blankenship, G. Casassa, G. Catania, D. Callens, H. Conway, A. J. Cook, H. F. J. Corr, D. Damaske, V. Damm, F. Ferraccioli, R. Forsberg, S. Fujita, Y. Gim, P. Gogineni, 
J. A. Griggs, R. C. A. Hindmarsh, P. Holmlund, J. W. Holt, R. W. Jacobel, A. Jenkins, W. Jokat, T. Jordan, E. C. King, J. Kohler, W. Krabill, M. Riger-Kusk, K. A. Langley, G. Leitchenkov, C. Leuschen, B. P. Luyendyk, K. Matsuoka, J. Mouginot, F. O. Nitsche, Y. Nogi, O. A. Nost, S. V. Popov, E. Rignot, D. M. Rippin, A. Rivera, J. Roberts, N. Ross, M. J. Siegert, A. M. Smith, D. Steinhage, M. Studinger, B. Sun, B. K. Tinto, B. C. Welch, D. Wilson, D. A. Young, C. Xiangbin, and A. Zirizzotti (2013), Bedmap2: improved ice bed, surface and thickness datasets for antarctica, The Cryosphere, 7(1), 375-393, doi:10.5194/tc-7-375-2013, tC.

Fürst, J. J., G. Durand, F. Gillet-Chaulet, L. Tavard, M. Rankl, M. Braun, and O. Gagliardini (2016), The safety band of Antarctic ice shelves, Nature Clim. Change, advance online publication, doi:10.1038/nclimate2912http://www.nature.com/nclimate/journal/ vaop/ncurrent/abs/nclimate2912.html\#supplementary-information.

Gudmundsson, G. H. (2013), Ice-shelf buttressing and the stability of marine ice sheets, The Cryosphere, 7(2), 647-655, doi:10.5194/tc-7-647-2013, tC.

Holland, P. R., A. Brisbourne, H. F. J. Corr, D. McGrath, K. Purdon, J. Paden, H. A. Fricker, F. S. Paolo, and A. H. Fleming (2015), Oceanic and atmospheric forcing of Larsen C Ice-Shelf thinning, The Cryosphere, 9(3), 1005-1024, doi:10.5194/tc-9-1005-2015.

Huang, B., V. F. Banzon, E. Freeman, J. Lawrimore, W. Liu, T. C. Peterson, T. M. Smith, P. W. Thorne, S. D. Woodruff, and H.-M. Zhang (2015), Extended Reconstructed Sea Surface Temperature Version 4 (ERSST.v4). 
Part I: Upgrades and intercomparisons, Journal of Climate, 28(3), 911930, doi:10.1175/JCLI-D-14-00006.1.

Huss, M., and D. Farinotti (2014), A high-resolution bedrock map for the Antarctic Peninsula, The Cryosphere, 8(4), 1261-1273, doi:10.5194/ tc-8-1261-2014, tC.

James, T. D., T. Murray, N. Selmes, K. Scharrer, and M. O'leary (2014), Buoyant flexure and basal crevassing in dynamic mass loss at Helheim Glacier, Nature Geosci, 7(8), 593-596, doi: 10.1038/ngeo2204http://www.nature.com/ngeo/journal/v7/n8/abs/ ngeo2204.html\#supplementary-information, [rsquor].

Jones, P. D., and D. H. Lister (2014), Antarctic near-surface air temperatures compared with ERA-Interim values since 1979, International Journal of Climatology, 35(7), 1354-1366, doi:10.1002/joc.4061.

Khazendar, A., C. P. Borstad, B. Scheuchl, E. Rignot, and H. Seroussi (2015), The evolving instability of the remnant Larsen B Ice Shelf and its tributary glaciers, Earth and Planetary Science Letters, 419, 199-210, doi:http://dx. doi.org/10.1016/j.epsl.2015.03.014.

Levitus, S., J. Antonov, O. K. Baranova, T. Boyer, C. Coleman, H. Garcia, A. Grodsky, D. Johnson, R. Locarnini, A. V. Mishonov, C. O'Brien, J. Reagan, D. Seidov, I. Smolyar, and M. Zweng (2013), The world ocean database, Data Science Journal, 12(0), WDS229-WDS234.

Luckman, A., D. I. Benn, F. Cottier, S. Bevan, F. Nilsen, and M. Inall (2015), 
Calving rates at tidewater glaciers vary strongly with ocean temperature, Nat Commun, 6, doi:10.1038/ncomms9566.

Martín-Español, A., A. Zammit-Mangion, P. J. Clarke, T. Flament, V. Helm, M. A. King, S. B. Luthcke, E. Petrie, F. Rémy, N. Schön, B. Wouters, and J. L. Bamber (2016), Spatial and temporal Antarctic ice sheet mass trends, glacio-isostatic adjustment, and surface processes from a joint inversion of satellite altimeter, gravity, and GPS data, Journal of Geophysical Research: Earth Surface, pp. 1-18, doi:10.1002/2015JF003550.

McMillan, M., A. Shepherd, A. Sundal, K. Briggs, A. Muir, A. Ridout, A. Hogg, and D. Wingham (2014), Increased ice losses from Antarctica detected by CryoSat-2, Geophysical Research Letters, 41(11), 2014GL060,111, doi:10.1002/2014GL060111.

Meredith, M. P., and J. C. King (2005), Rapid climate change in the ocean west of the Antarctic Peninsula during the second half of the 20th century, Geophysical Research Letters, 32(19), L19,604, doi:10.1029/ 2005 GL024042.

Nick, F. M., and J. Oerlemans (2006), Dynamics of tidewater glaciers: Comparison of three models, Journal of Glaciology, 52(177), 183-190, doi: $10.3189 / 172756506781828755$.

Nick, F. M., A. Vieli, M. L. Andersen, I. Joughin, A. Payne, T. L. Edwards, F. Pattyn, and R. S. W. van de Wal (2013), Future sea-level rise from Greenland's main outlet glaciers in a warming climate, Nature, 497(7448), 
235-238, doi:10.1038/nature12068http://www.nature.com/nature/ journal/v497/n7448/abs/nature12068.html\#supplementary-information.

O'Leary, M., and P. Christoffersen (2013), Calving on tidewater glaciers amplified by submarine frontal melting, The Cryosphere, 7(1), 119-128, doi: 10.5194/tc-7-119-2013, tC.

Pelto, M. S., and C. R. Warren (1991), Relationship between tidewater glacier calving velocity and water depth at the calving front, Annals of Glaciology, $15,115-118$.

Pritchard, H. D., and D. G. Vaughan (2007), Widespread acceleration of tidewater glaciers on the Antarctic Peninsula, Journal of Geophysical Research: Earth Surface, 112(F3), n/a-n/a, doi:10.1029/2006JF000597.

Pritchard, H. D., S. R. M. Ligtenberg, H. A. Fricker, D. G. Vaughan, M. R. van den Broeke, and L. Padman (2012), Antarctic ice-sheet loss driven by basal melting of ice shelves, Nature, 484 (7395), 502-505, doi:http://www.nature.com/nature/journal/v484/ n7395/abs/nature10968.html, 10.1038/nature10968.

Radić, V., A. Bliss, A. C. Beedlow, R. Hock, E. Miles, and J. G. Cogley (2014), Regional and global projections of twenty-first century glacier mass changes in response to climate scenarios from global climate models, Climate Dynamics, 42(1-2), 37-58, doi:10.1007/s00382-013-1719-7.

Rignot, E., and P. Kanagaratnam (2006), Changes in the velocity structure of the Greenland ice sheet, Science, 311 (5763), 986-990, doi:10.1126/science. 1121381. 
Rignot, E., G. Casassa, P. Gogineni, W. Krabill, A. Rivera, and R. Thomas (2004), Accelerated ice discharge from the Antarctic Peninsula following the collapse of Larsen B ice shelf, Geophysical Research Letters, 31(18), L18,401, doi:10.1029/2004GL020697.

Rignot, E., J. Mouginot, and B. Scheuchl (2011), Ice flow of the Antarctic ice sheet, Science, 333(6048), 1427-1430, doi:10.1126/science.1208336.

Ritz, C., T. L. Edwards, G. Durand, A. J. Payne, V. Peyaud, and R. C. A. Hindmarsh (2015), Potential sea-level rise from Antarctic ice-sheet instability constrained by observations, Nature, 528(7580), 115-118, doi:10.1038/nature16147http://www.nature.com/nature/journal/v528/ n7580/abs/nature16147.html\#supplementary-information.

Rott, H., W. Rack, P. Skvarca, and H. De Angelis (2002), Northern Larsen Ice Shelf, Antarctica: Further retreat after collapse, Annals of Glaciology, 34 (1), 277-282, doi:10.3189/172756402781817716.

Rott, H., D. Floricioiu, J. Wuite, S. Scheiblauer, T. Nagler, and M. Kern (2014), Mass changes of outlet glaciers along the Nordensjköld Coast, northern Antarctic Peninsula, based on TanDEM-X satellite measurements, Geophysical Research Letters, p. 2014GL061613, doi:10.1002/ 2014GL061613.

Scambos, T., C. Hulbe, and M. Fahnestock (2003), Climate-Induced Ice Shelf Disintegration in the Antarctic Peninsula, pp. 79-92, American Geophysical Union, doi:10.1029/AR079p0079. 
Scambos, T. A., C. Hulbe, M. Fahnestock, and J. Bohlander (2000), The link between climate warming and break-up of ice shelves in the Antarctic Peninsula, Journal of Glaciology, 46 (154), 516-530, doi:10.3189/ 172756500781833043.

Scambos, T. A., J. A. Bohlander, C. A. Shuman, and P. Skvarca (2004), Glacier acceleration and thinning after ice shelf collapse in the Larsen B embayment, Antarctica, Geophysical Research Letters, 31(18), n/a-n/a, doi:10.1029/2004GL020670.

Scambos, T. A., E. Berthier, T. Haran, C. A. Shuman, A. J. Cook, S. R. M. Ligtenberg, and J. Bohlander (2014), Detailed ice loss pattern in the northern Antarctic Peninsula: Widespread decline driven by ice front retreats, The Cryosphere, 8(6), 2135-2145, doi:10.5194/tc-8-2135-2014, tC.

Schannwell, C., N. E. Barrand, and V. Radić (2015), Modeling ice dynamic contributions to sea level rise from the Antarctic Peninsula, Journal of Geophysical Research: Earth Surface, 120(11), 2374-2392, doi:10.1002/ 2015JF003667.

Schoof, C. (2007), Ice sheet grounding line dynamics: Steady states, stability, and hysteresis, Journal of Geophysical Research: Earth Surface, 112(F3), F03S28, doi:10.1029/2006JF000664.

Shepherd, A., D. Wingham, T. Payne, and P. Skvarca (2003), Larsen Ice Shelf has progressively thinned, Science, 302(5646), 856-859, doi:10.1126/ science.1089768. 
Straneo, F., G. S. Hamilton, D. A. Sutherland, L. A. Stearns, F. Davidson, M. O. Hammill, G. B. Stenson, and A. Rosing-Asvid (2010), Rapid circulation of warm subtropical waters in a major glacial fjord in East Greenland, Nature Geosci, 3(3), 182-186, doi:http://www.nature.com/ngeo/journal/ v3/n3/suppinfo/ngeo764_S1.html, 10.1038/ngeo764.

Taylor, K. E., R. J. Stouffer, and G. A. Meehl (2011), An overview of CMIP5 and the experiment design, Bulletin of the American Meteorological Society, 93(4), 485-498, doi:10.1175/BAMS-D-11-00094.1.

van den Broeke, M. (2005), Strong surface melting preceded collapse of Antarctic Peninsula ice shelf, Geophysical Research Letters, 32(12), L12,815, doi:10.1029/2005GL023247.

van der Veen, C. J. (1996), Tidewater calving, Journal of Glaciology, 42(141), $375-385$.

Vaughan, D., G. Marshall, W. Connolley, C. Parkinson, R. Mulvaney, D. Hodgson, J. King, C. Pudsey, and J. Turner (2003), Recent rapid regional climate warming on the Antarctic Peninsula, Climatic Change, 60(3), 243-274, doi:10.1023/A:1026021217991.

Vaughan, D. G., and C. S. M. Doake (1996), Recent atmospheric warming and retreat of ice shelves on the Antarctic Peninsula, Nature, 379 (6563), 328-331, 10.1038/379328a0.

Vieli, A., M. Funk, and H. Blatter (2001), Flow dynamics of tidewater glaciers: A numerical modelling approach, Journal of Glaciology, 47(159), 595-606, doi:10.3189/172756501781831747. 
${ }_{724}$ Vuuren, D. P., J. Edmonds, M. Kainuma, K. Riahi, A. Thomson, K. Hib${ }_{725}$ bard, G. C. Hurtt, T. Kram, V. Krey, J.-F. Lamarque, T. Masui, M. Mein726 shausen, N. Nakicenovic, S. J. Smith, and S. K. Rose (2011), The repre${ }_{227}$ sentative concentration pathways: An overview, Climatic Change, 109(1), $728 \quad$ 5-31, doi:10.1007/s10584-011-0148-z.

${ }_{729}$ Wouters, B., A. Martín-Español, V. Helm, T. Flament, J. M. van Wessem, ${ }_{730}$ S. R. M. Ligtenberg, M. R. van den Broeke, and J. L. Bamber (2015), ${ }_{731}$ Dynamic thinning of glaciers on the southern Antarctic Peninsula, Science, $732348(6237), 899-903$, doi:10.1126/science.aaa5727. 
Figure 1: (a) Gamma distributions used in grounding line retreat parameterisation for different mean adjustment times (M). (b) Sample of 100 random step-response functions for corresponding $\mathrm{M}=20$ curve in (a).

\begin{tabular}{llll}
\hline Ice Shelf & Mean Retreat $[\mathrm{m}]$ & $\Theta$ & No. of basins \\
\hline Larsen B & 691 & 0.47 & 6 \\
Larsen C North & 405 & 0.40 & 17 \\
Larsen C South & 215 & 0.59 & 31 \\
Larsen D North & 656 & 0.60 & 16 \\
Larsen D Central & 250 & 0.57 & 11 \\
Larsen D South & 4140 & 0.66 & 20 \\
George VI North & 1960 & 0.52 & 4 \\
George VI Central & 7310 & 0.69 & 3 \\
George VI South & 10530 & 0.69 & 8 \\
Stange & 29540 & 0.54 & 1 \\
\hline
\end{tabular}

Table 1: Ice-shelf grounding line retreat distances, mean buttressing factor $(\Theta)$, and the number of basins for each ice shelf entity.

Figure 2: Multi model mean ocean temperatures for the ice-sheet model domain for RCP4.5 (blue line) and RCP8.5 (red line). Shading shows $( \pm 1 \sigma)$ uncertainty.

Figure 3: SLR projection from tidewater glaciers permitting calving front retreat to 2100 (a) and to 2300 (b). Shading shows $( \pm 1 \sigma)$ uncertainty. 
Figure 4: Multi model mean melt day projections for all ice shelves for the RCP4.5 (solid blue line) and RCP8.5 (solid red line) scenarios. Shading shows $( \pm 1 \sigma)$ uncertainty. Dashed blue lines and dashed red lines denote ice-shelf collapse timing for the RCP4.5 and RCP8.5 scenarios, respectively. Dashed black line approximates collapse threshold. Note that for Scar Inlet collapse timing for both scenarios is forecasted for the same year.

Figure 5: Combined SLR for RCP4.5 (a) and RCP8.5 (b) scenarios. Red and blue line correspond to combined minimum and combined maximum projection. Dashed blue lines approximate timing of ice-shelf collapse. Error bars are displayed where available. 


\section{${ }_{733}$ Appendix A. Ocean temperature bias}

Figure A.6: Ocean temperature bias in comparison to ERSST v4 from 1979-2005 for each

734 GCM. Dashed black line indicates multi model mean $\left(-0.6 \pm 0.7^{\circ} \mathrm{C}\right)$.

735 
736

\section{Appendix B. GCM temperature bias}

Figure B.7: Near-surface temperature bias in comparison to ERA Interim from 1979-2005.

Dashed black line indicates multi model mean $\left(2.0 \pm 2.6^{\circ} \mathrm{C}\right)$.

738

739

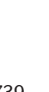

740

Table B.2: List of weather
Automatic Weather Station.

\begin{tabular}{lllll}
\hline Station & Type & Lat & Lon & Height (m.a.s.I) \\
\hline Bellinghausen & Surface & -62.2 & -58.9 & 16 \\
Biscoe Island & AWS & -66.0 & -66.1 & 20 \\
Bonaparte Point & AWS & -64.8 & -64.1 & 8 \\
Cape Adams & AWS & -75.0 & -62.5 & 25 \\
Deception & Surface & -63.0 & -60.7 & 8 \\
Dismal Island & AWS & -68.1 & -68.8 & 10 \\
Dolleman Island & AWS & -70.6 & -60.9 & 396 \\
Fossil Bluff & AWS & -71.3 & -68.3 & 66 \\
Jubany & Surface & -62.2 & -58.6 & 4 \\
Kirkwood Island & AWS & -68.3 & -69.0 & 30 \\
Limbert & AWS & -75.9 & -59.2 & 58 \\
Marambio & Surface & -64.8 & -64.1 & 198 \\
Marsh & Surface & -62.2 & -59.0 & 10 \\
Racer Rock & AWS & -64.1 & -61.6 & 17 \\
Sky Blue & AWS & -74.8 & -71.5 & 1556 \\
Uranus Glacier & AWS & -71.4 & -68.8 & 753 \\
\hline
\end{tabular}



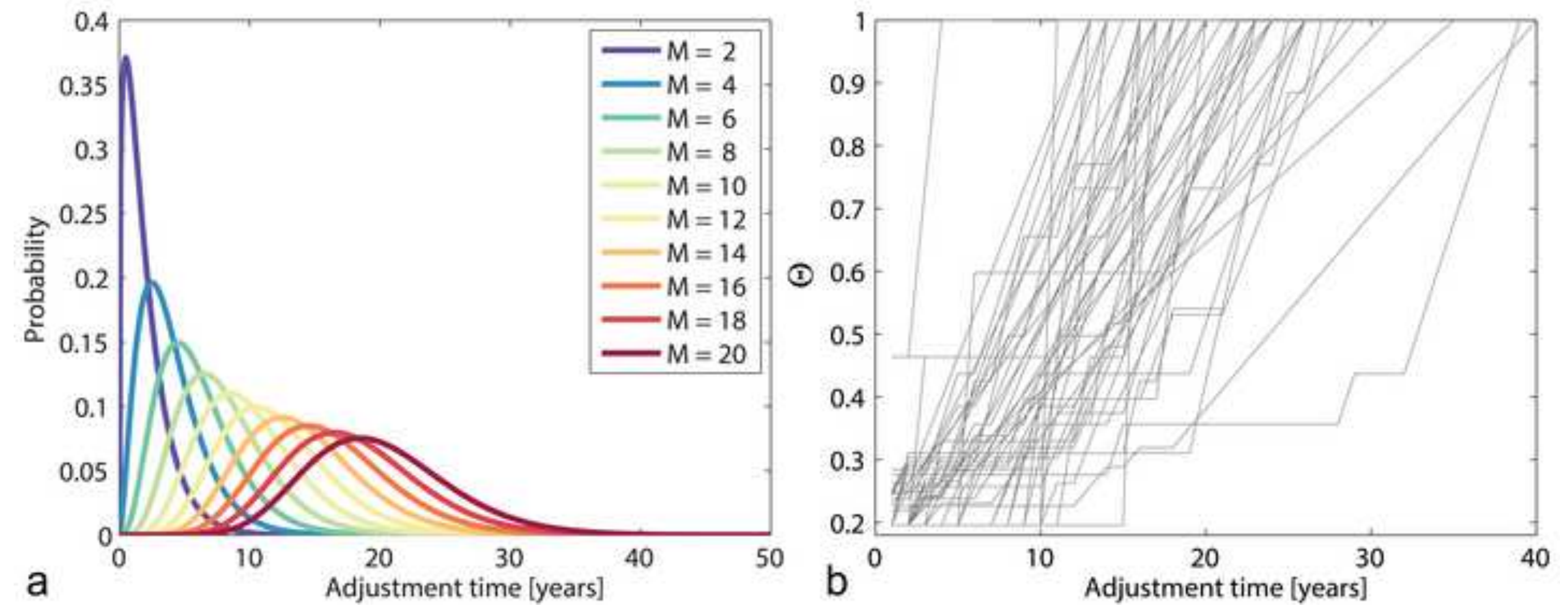

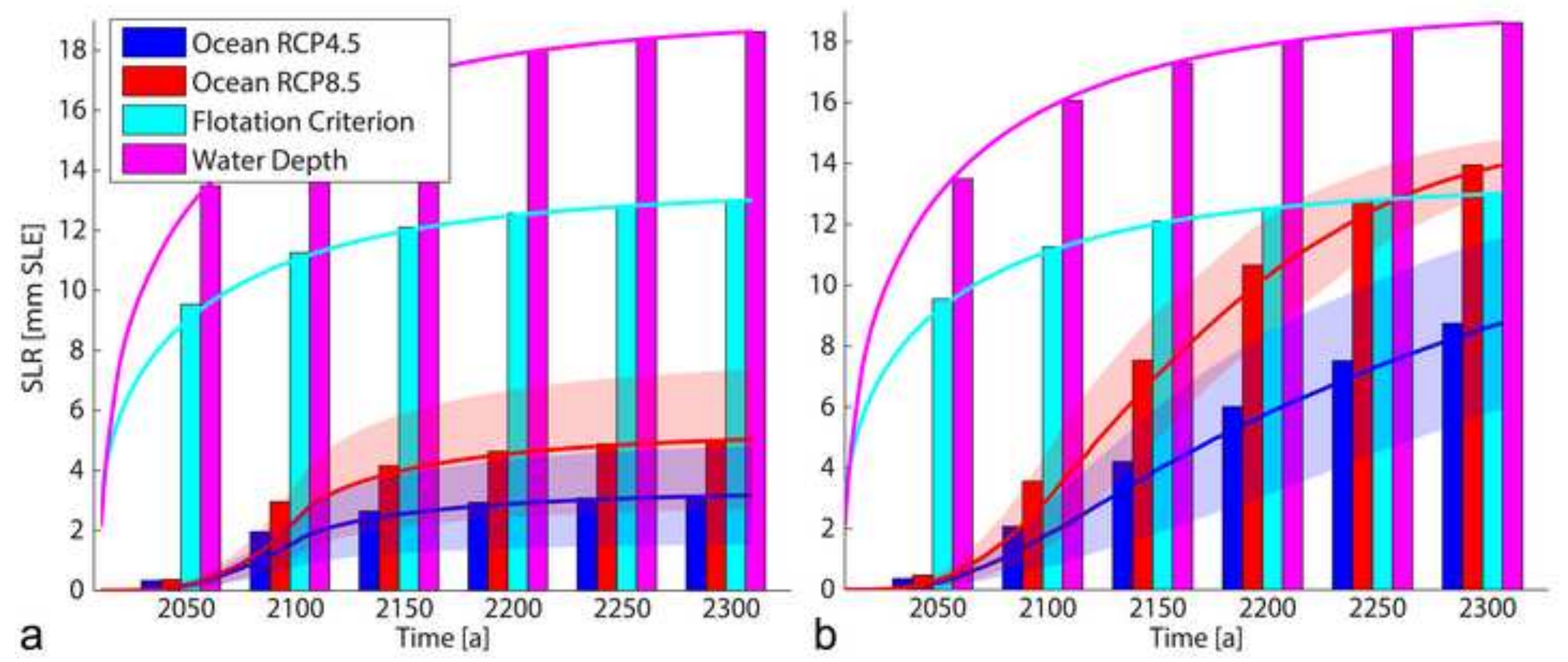

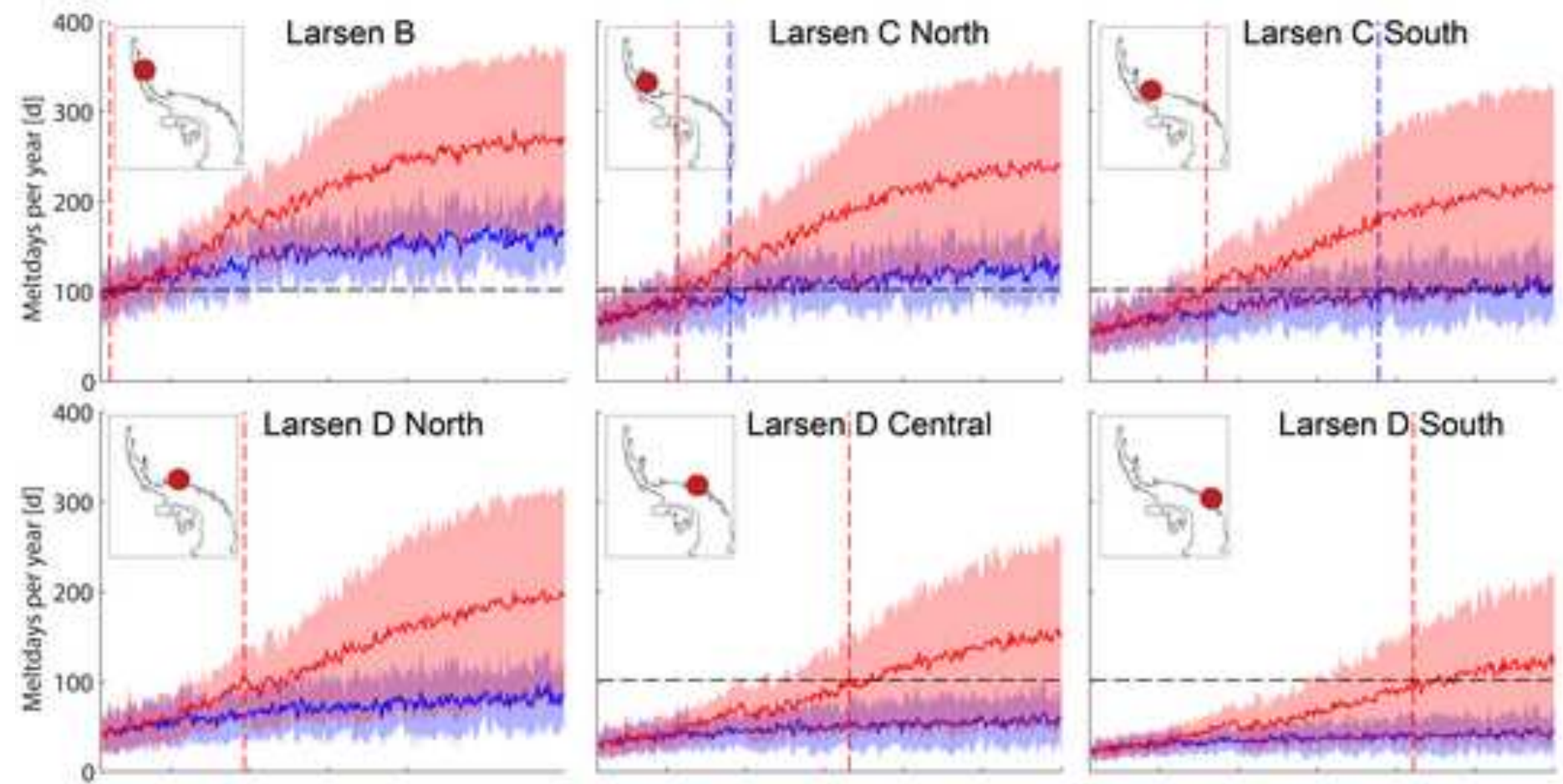

Larsen D South
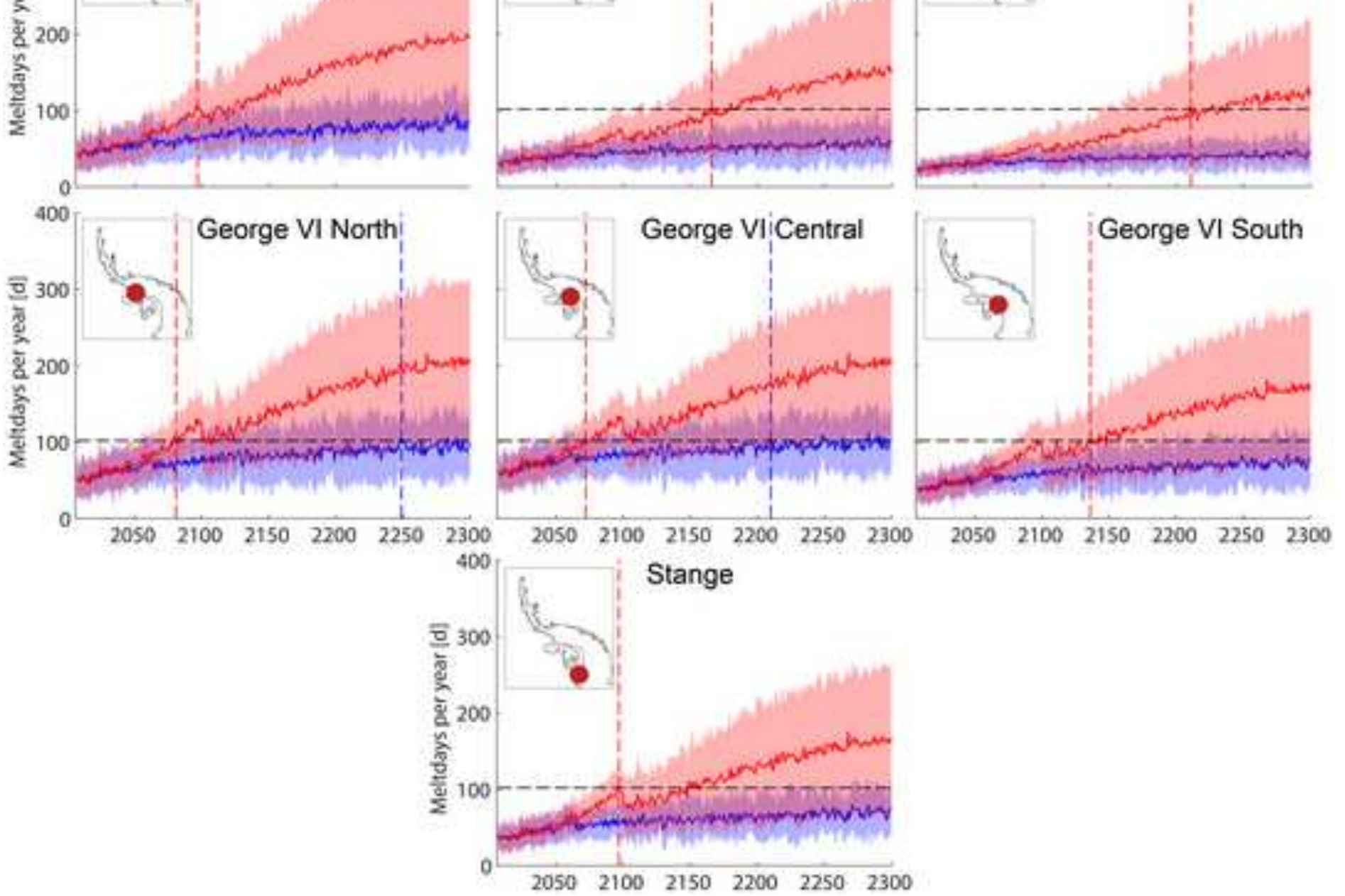

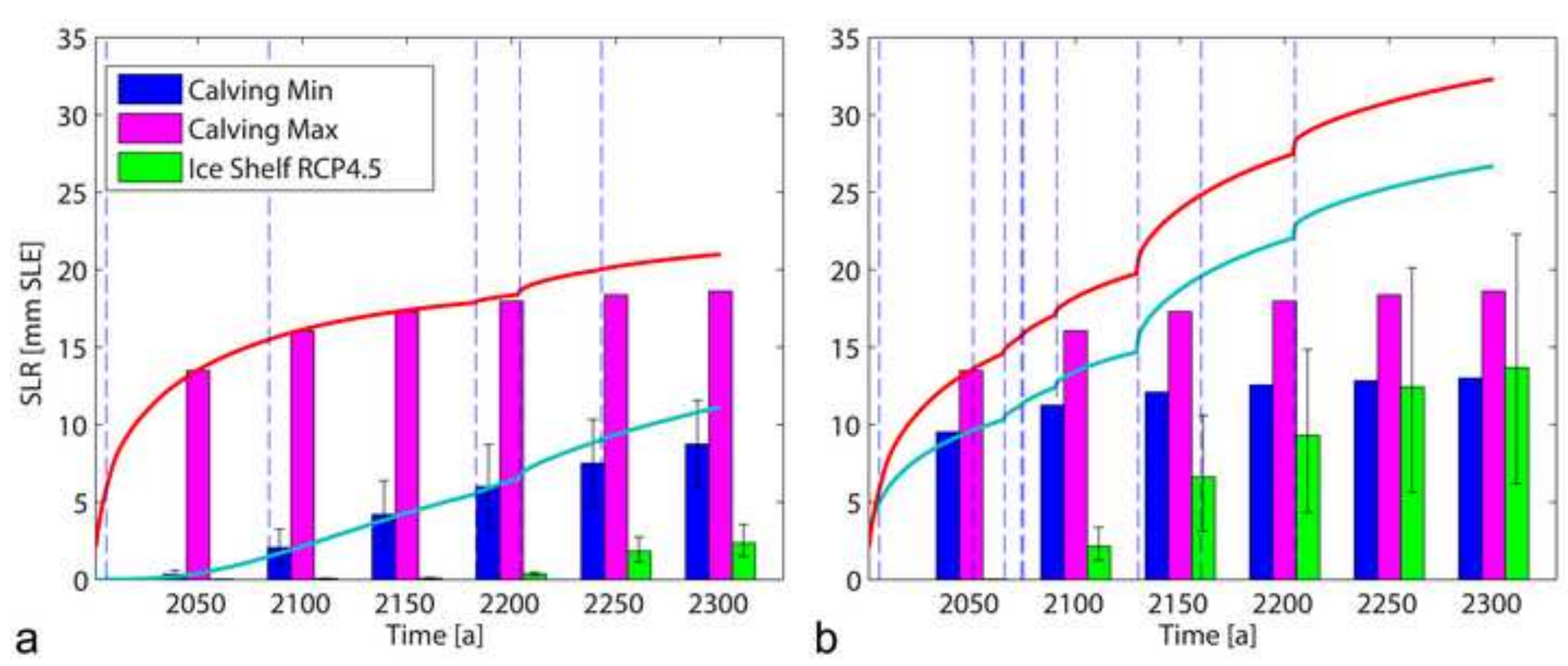


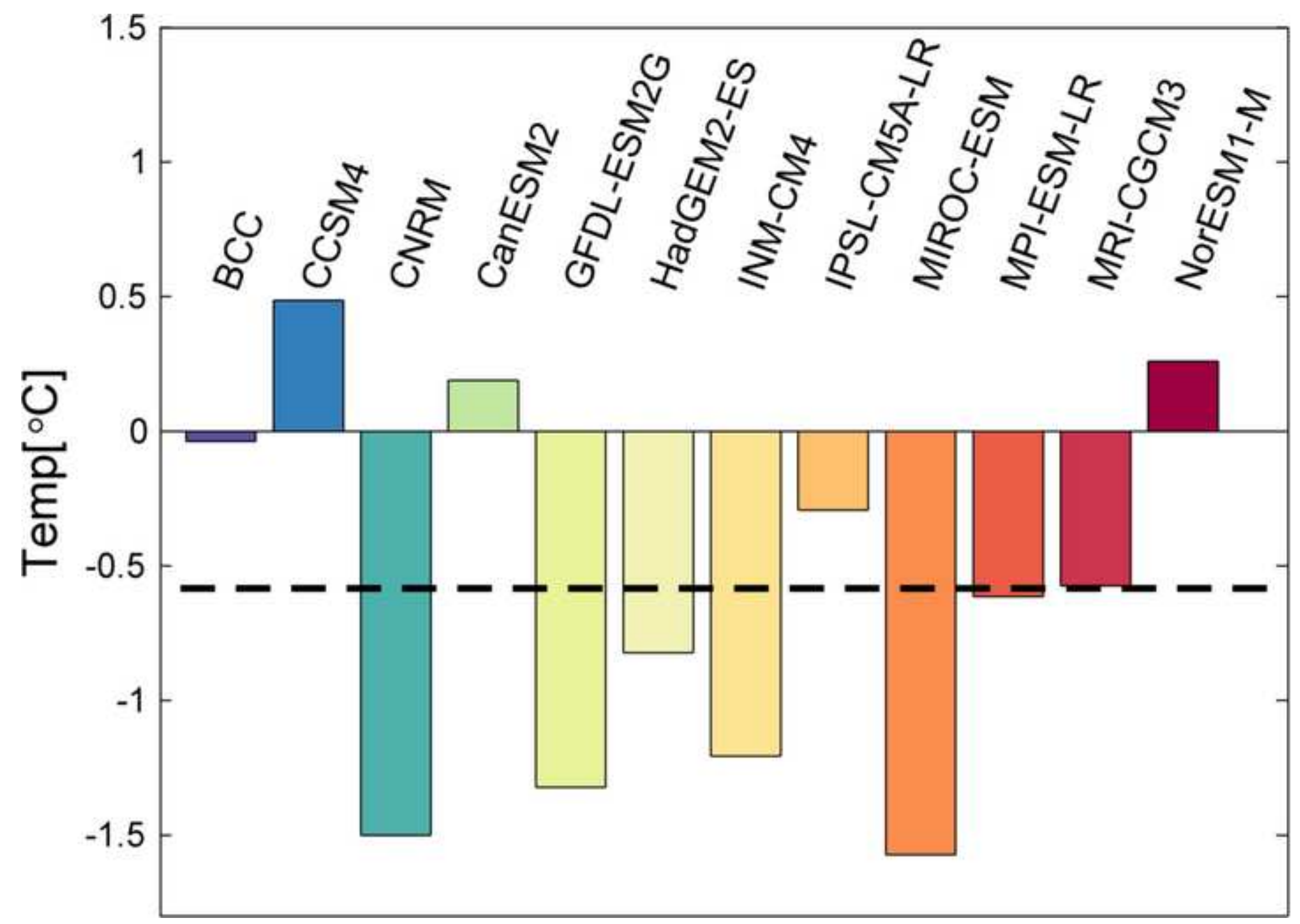




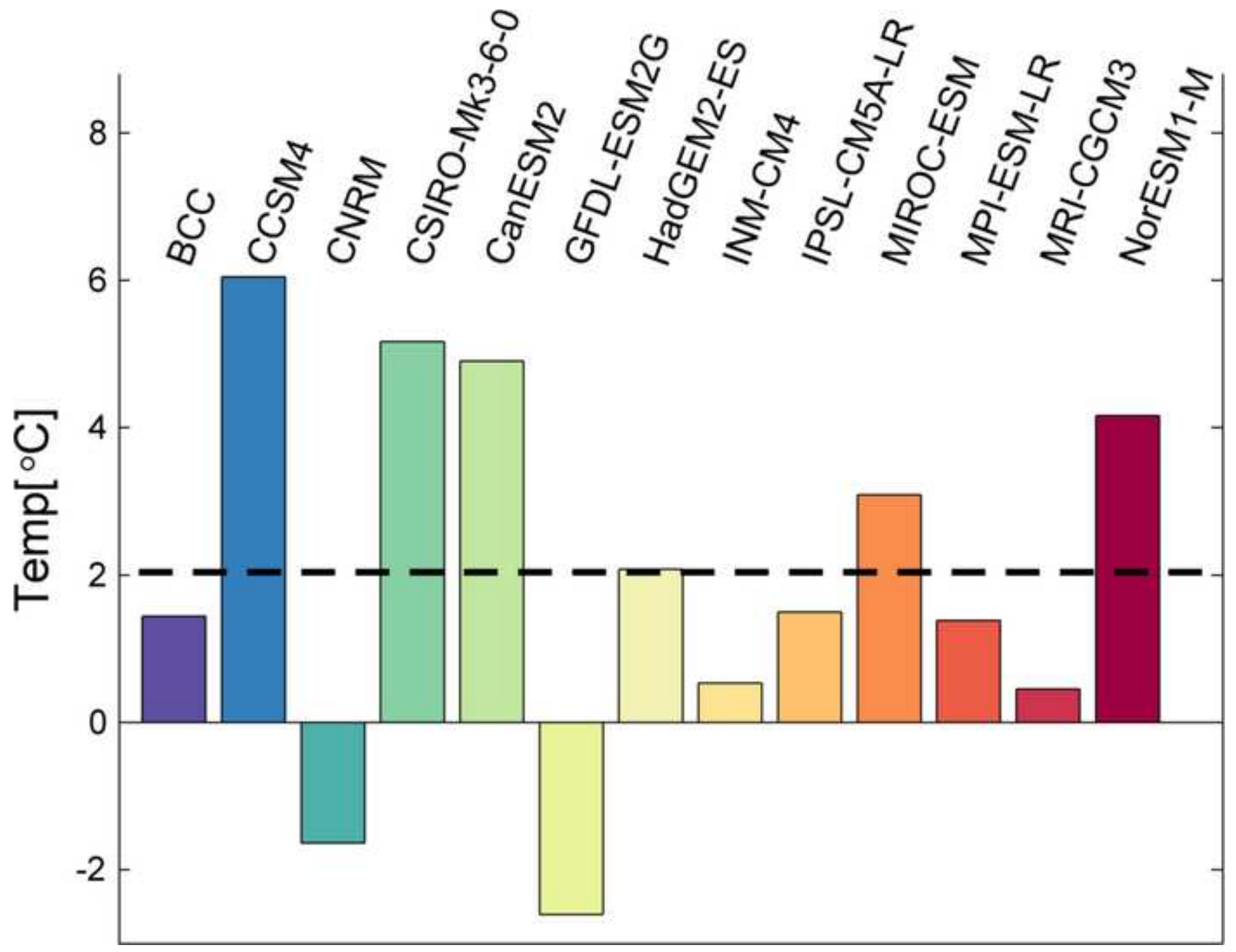

